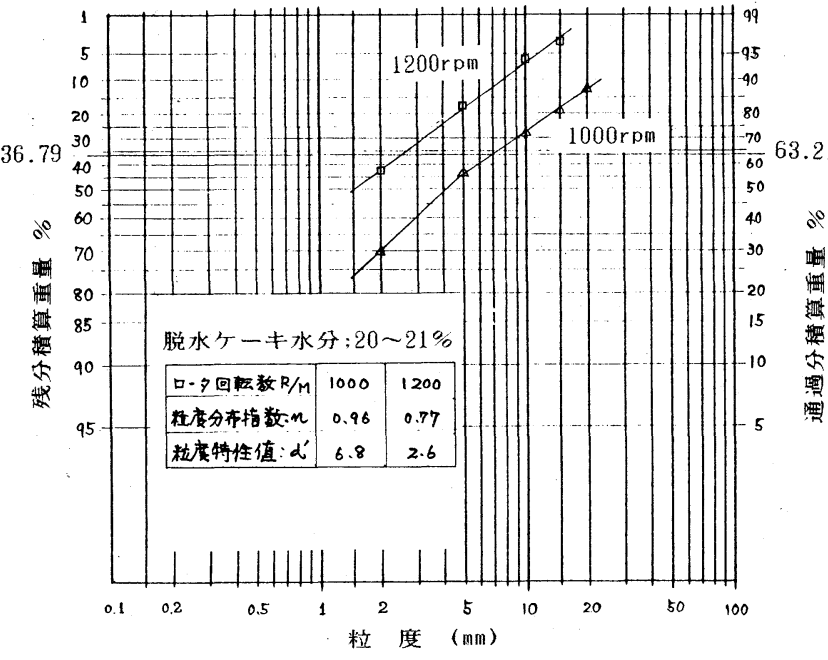

第 4 図 選炭廃水ケーキ解砕産物粒度分布

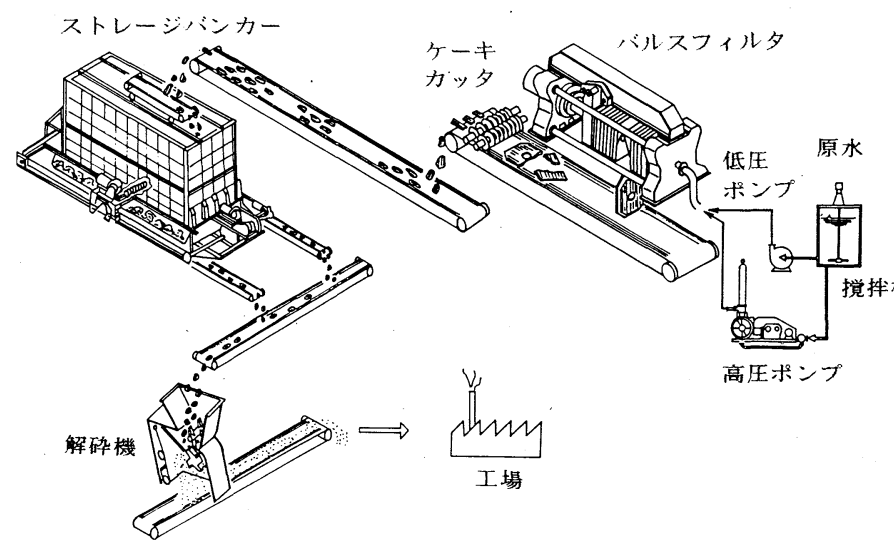

第 5 図 脱水・解䂶システムの標準フロー

定量給鉱を確保するフローとなつている。難脱水性のスラリーを 効果的に脱水する機種としては, フィルタプレスが最適と考えら れるが，バッチシステムであるため間欠的にケーキが排出され次 工程に連続供給できないウィークポイントを有していた。ストレ ージ・バンカをプレスと解砕機の間に挿入することによつて, 解 碎工程以降の連続操業が容易となり次のような工業分野のリサイ クルシステム機器として応用が可能と考えている。

（1）選炭脱水ケーキ( 低カロリー炭）

$\mathrm{F} \cdot \mathrm{P}$ ケーキ $\rightarrow$ 解砕 $\rightarrow$ 混炭 $\rightarrow$ 発電所 ……熱源として有効利用
微粉炭

（2）製鉄ダスト脱悪鉛ケーキ

$\mathrm{F} \cdot \mathrm{P}$ ケーキ $\rightarrow$ 解碎 $\rightarrow$ 造粒 $\rightarrow$ 焼結工場……鉄源として有効利用
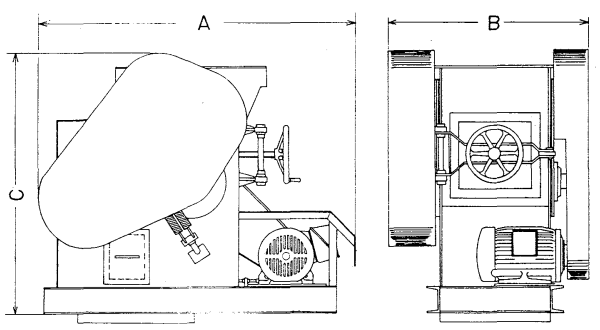

第6図 カイサイザ寸法図

第1表 カイサイザの能力および標準仕様

\begin{tabular}{|c|c|c|c|c|c|}
\hline \multirow{3}{*}{\multicolumn{2}{|c|}{$\begin{array}{l}\frac{\text { 型 }}{} \text { 式 } \\
\text { 処理量 } \mathrm{m}^{3} / \mathrm{hr} \\
\text { 据付動力 } \mathrm{kW}\end{array}$}} & $\mathrm{RC}-01$ & $\mathrm{RC}-02$ & $\mathrm{RC}-03$ & $\mathrm{RC}-04$ \\
\hline & & 13 & 25 & 35 & 45 \\
\hline & & 75 & 15 & 22 & 30 \\
\hline \multirow{3}{*}{ 寸法 } & 長さ*(A) & 1,000 & 1,180 & 1,300 & 1,500 \\
\hline & 幅 ${ }^{*}$ (B) & 850 & 1,150 & 1,500 & 1,900 \\
\hline & 高さ*(C) & 1,395 & 1,395 & 1,530 & 1,800 \\
\hline
\end{tabular}

（3）上下水道污泥

$\mathrm{F} \cdot \mathrm{P}$ ケーキ $\rightarrow$ 解砕 $\rightarrow$ 焼却工場……熱源・燃焼効率のアップ
微粉炭
による省エネルギー化

（4）各種工業における漫出残滓

$\mathrm{F} \cdot \mathrm{P}$ ケーキ $\rightarrow$ 解砕 $\rightarrow$ 乾燥工程…………表面積増加による省

(5) 砕石脱水ケーキ

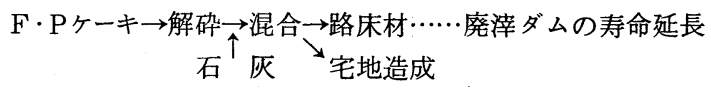

（6）河川, 湖沼沈積污泥

$\mathrm{F} \cdot \mathrm{P}$ ケーキー解砕 $\rightarrow$ 混合
固結剤
築堤材

\section{5. カイサイザの能力および標準仕様}

カイサイザの機種および標準仕様を第 1 表および第 6 図に示 す。

6. おわりに

脱水ケーキの解砕・整粒を行なうことは, 以上述べたように省 エネルギー化，未利用資源の有効活用に寄与する所大であり，そ のニーズは強い。カイサイザは，これらニーズと期待に応えるべ く開発されたものである。しかし剪断破䂶方式を採用し，原料の 性状等の影響を受け難いとは云うもののまだまだ問題が残つてい る。今後, 皆様のご意見, ご指導を賜わりながらより良い解砕機 にしたいと考えている次第である。

〔新技術紹介〕

（3）夕張市地域エネルギー開発ボイラ事業について

(株)石炭の歷史村観光 中 田 鉄 治 (株)北建エンシシニアリング 小 林 数 夫

\section{1. まえがき}

今春以来「(株) 石炭の歴史村観光」の事業の一端として「地域エ
ネルギー開発ボイラ事業」が完工し熱供給センターが操業を開始 したので, 皆様方にこの一連のボイラプラントに関する姿を知つ ていただくため, その概要および特徴等について発表させて頂く。 はじめに当事業計画は, 昭和58年度「地域エネルギー開発利用 
モデル事業」として通産省のご採択を賜り，道，地域振興整備公 団, 道・東北開発公庫, その他関係諸機関より, 多大のご協力恶び にご指導を賜り，過疎化になやむ産炭都市の活性化に大きな弾み となつたことに対し，心から厚く感謝申し上げる次第である。

\section{2. 一 般 概 要}

本事業は昭和 56 年，ちようど国策として「エネルギー転換」が 強力に叫ばれていた時期から企画検討が開始された。

夕張市という産炭地として国内の代表的な都市が市役所，病院 ・市民会館, および市の起死回生策として企画された「(株)石炭の 歷史村観光」の諸施設までも「エネルギー源」を輸入原油に依存す る不合理性からの検討であつた。企画検討の結果, 総延長約 3.7 $\mathrm{km}$ におよぶ配管群の布設を実施すれば主要施設がすべて網羅さ れることが判明した。

また幸いなことに，この配管網のほぼ中心位置に，昭和 52 年 9 月に廃缶のまま残置されていた旧北炭夕張新第二炭鉱の総合ボイ ラ設備,つねきちCD-150型, HN-300型 各 1 基があつた。缶体 調査の結果, その主要部 (圧力容器部) は極めて良好に保存され, 将来長期的にも十分使用可能であることが判り, このボイラの復 活使用の検討に入つた。

夕張市ならびにその周辺炭鉱には，産業廃棄物に類する産炭地 特有の「低カロリー炭ならびに廃坑木」等の「ローカル色」豊か な未利用資源が，長い歴史を物語るように残置または副産されて いる。この種の燃料を用い, 有効に燃焼させうる燃焼機構の選択, しかも復活缶の構造を安価に, かつ上手に活用する方法が一番の 課題であつた。種々の検討の結果，当時同市楓の真谷地炭鉱にお いて実用缶として試用中の北炭 H S 型低品位炭ボイラの ${ }^{a)}$ 「傾斜 波動型」火格子を設計替えの上採用することに決定した。本装置 を水管ボイラに付帯させたのは今般が初めてであり，幾多の細部 ノウハウを包含している。

本プラントには，いくつかの新しい試みが勘案されている。も ちろんそれらは特殊な燃料を採用することに対応したものがほと んどである。しかしながら私達は，近年なかなか見られなくなつ たこの種の旧ボイラ (昭和 28 年建造 )を単に近代的装備と自動化 によつて変貌させるだけでなく, 当初の外観を変えることなく復 元し，熱供給事業としての目的を十分果した上，なお石炭ボイラ の歴史の一片を産炭地夕張の「石炭の歴史村」に存続させること に大きな意義を感じている次第である。

\section{3. 使用燃料について}

\section{$3 \cdot 1$ 構成内容}

（1）廃材チップ 閉山過疎化対策事業として推進中の炭鉱廃 屋解体に伴う廃材および稼働炭鉱より発生する古矢木等の回収廃 材をチップ化したものである。

（2）廃棄物脱水ケーキ 炭鉱の選炭工程にお打る最終廃棄物 であり，環境污染等のため河川に放流できずフイルタプレスで脱 水し，ケーキ状に固め投棄しているものである。

（3）市販不能微分市販銘柄がなく, 山焚処理または, 山元 自家発にも適用困難な下級沈殿粉等である。

$3 \cdot 2$ 発熱量と混合比

\begin{tabular}{|c|c|c|}
\hline & 高位発燃量 kcal/kg & 混合比率\% \\
\hline 廃材チップ & 3,400 & 40 \\
\hline 脱水ケーキ & 2,500 & 30 \\
\hline 徽 粉 & 3,900 & 30 \\
\hline 混 合 燃 料 & 3,280 & 100 \\
\hline
\end{tabular}

a）昭和58 年度第33回全国選炭大会において発表済
$3 \cdot 3$ 燃料の性状

(1) 廃材チップ

$\begin{array}{llr}\text { 灰 分 } & & 3.0 \% \\ \text { 水 分 } & & 20.0 \% \\ \text { 元素組成 } & \mathrm{C} & 42.0 \% \\ \text { 元素組成 } & \mathrm{H} & 6.5 \% \\ & \mathrm{O} & 51.5 \%\end{array}$

（2）脱水ケーキ之微粉の半々混合物

$\begin{array}{lr}\text { 灰 分 } & 54.0 \% \\ \text { 固有水分 } & 2.4 \% \\ \text { 揮 発 分 } & 25.8 \% \\ \text { 固定炭素 } & 17.8 \% \\ \text { 硫 黄 分 } & 0.2 \% \\ \text { 水素 ( 無水換算 ) } & 4.0 \% \\ \text { 表面付着水分 } & 20.0 \%\end{array}$

$3 \cdot 4$ 特 徵

着火および燃焼速度の早いチップ材を，高含有水分で着火の遅 い低カロリ一廃棄物に混入することは, 燃料の助燃剂的役割を発 揮すると同時に発熱量の変動が大きい選炭廃棄物を使用する混合 燃料の品質安定を図る有効な組合せとなる。

また脱水ケーキはボイラに投入する前に一度解砕過程を経なけ ればならない。しかし解砕後缶前ホッパに搬送し，ストックする と再凝固し，極めて前処理に難行することが判明している。この 意味で解砕混合時にチップ材を混入することは，再凝固防止に大 きな効果をもたらす。

\section{4. 復元ボイラについて}

\section{$4 \cdot 1$ 適用法規，規格}

(1) ボイラ及圧力容器構造規格学働省 [ボイラ及び圧力容器安全規則] [ボイラ構造規格]

(2) 日本工業規格 ( J I S )

$4 \cdot 2$ ボイラ仕様

ボイラ型式＼cjkstart水管式傾斜波動床ボイラ

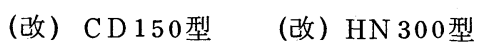

実最大蒸発量 $\quad 4,000 \mathrm{~kg} / \mathrm{h} \quad 8,000 \mathrm{~kg} / \mathrm{h}$

伝熱面積 $\quad 156.9 \mathrm{~m}^{2} \quad 315.4 \mathrm{~m}^{2}$

最高使用圧力 $7 \mathrm{~kg} / \mathrm{cm}^{2}$

常用圧力 $4 \mathrm{~kg} / \mathrm{cm}^{2}$ 飽和 $151^{\circ} \mathrm{C}$

使用燃料前 記 混合燃料

蒸汽用途暖房用 熱供給対象施設第 1 図参照 年間使用量 $\quad 22,000 \mathrm{t} /$ 年

然料消費量 ( 湿然料パース)

$$
1,540 \mathrm{~kg} / \mathrm{h} \quad 3,080 \mathrm{~kg} / \mathrm{h}
$$

公害対策

NOx： 1 次燃焼が還元雾囲気であること，また廃材チッ プを混合することなどから $250 \mathrm{PPM}$ 以下とする。

$\mathrm{SOX}$ : 燃料中の硫黄分が極めて少ないので特に考慮を要 しない。

ばいじん：フレクト・オプテイパルス・バグフイルタ 2 基を設置，規制値以下とする。

$4 \cdot 3$ ボイラ設計值 (次頁の表参照)

\section{5. 設備の特徴について}

$5 \cdot 1$ 燃料供給システム（第 2 図参照）

(1)ボイラ室スペースの制約条件からより確実性の高い揚燃料方 


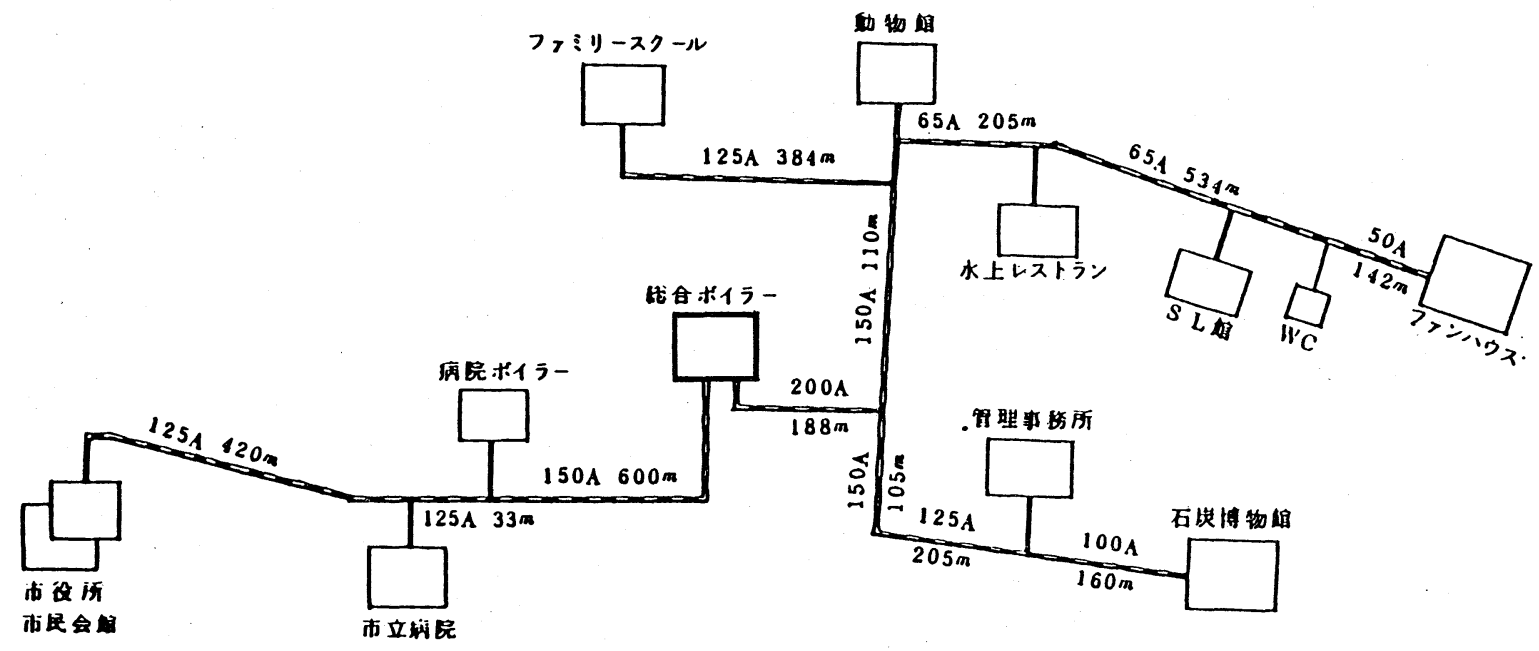

第1図夕張市施設配置図

\begin{tabular}{|c|c|c|c|}
\hline 項 & 単 位 & $\begin{array}{l}\text { (改) } \\
\text { CD-150 }\end{array}$ & $\begin{array}{l}\text { (改) } \\
\mathrm{HN}-300 \\
\end{array}$ \\
\hline 勢最大蒸発量 & $\mathrm{kg} / \mathrm{h}$ & 4,000 & 8,000 \\
\hline 排ガス損失 & & 22. 0 & 22.0 \\
\hline $\begin{array}{l}\text { 放射損疾 } \\
\text { 未燃飛散灰損失 }\end{array}$ & $\%$ & $\begin{array}{l}3.5 \\
2.5\end{array}$ & $\begin{array}{l}3.5 \\
2.5\end{array}$ \\
\hline その他の損失 & $\%$ & 2. 0 & 2. 0 \\
\hline ボイラ理論効率 & $\%$ & $\begin{array}{l}30.0 \\
70\end{array}$ & $\begin{array}{l}30.0 \\
70\end{array}$ \\
\hline 然料消費量 (湿燃料) & $\mathrm{kg} / \mathrm{h}$ & 1,540 & 3,080 \\
\hline 然焼室熱負荷 & $\mathrm{kcal} / \mathrm{m}^{2} \mathrm{~h}$ & 260,000 & 280,000 \\
\hline $\begin{array}{l}\text { 火格子面積負荷 } \\
\text { ガ ス 温 度 }\end{array}$ & $\mathrm{kg} / \mathrm{m}^{2} \mathrm{~h}$ & 250 & 270 \\
\hline 燃焼室出口 & ${ }^{\circ} \mathrm{C}$ & 416 & 416 \\
\hline 節炭器出口 & ${ }^{\circ} \mathrm{C}$ & 33 & 33 \\
\hline $\begin{array}{l}\text { 空気予熱器出口 } \\
\text { 䆓淐度 }\end{array}$ & ${ }^{\circ} \mathrm{C}$ & 179 & 179 \\
\hline 工押込空気予熱器入口 & ${ }^{\circ} \mathrm{C}$ & 5 & \\
\hline " " & ${ }^{\circ} \mathrm{C}$ & 90 & 90 \\
\hline 冷却空気予熱器入口 & ${ }^{\circ} \mathrm{C}$ & 5 & 5 \\
\hline 给水淐" "度口 & ${ }^{\circ} \mathrm{C}$ & 150 & 150 \\
\hline 節炭器入口 & ${ }^{\circ} \mathrm{C}$ & 5 & 5 \\
\hline "出口 & ${ }^{\circ} \mathrm{C}$ & 73 & 73 \\
\hline
\end{tabular}

部の移動式可逆コンベヤで供給方向を变え，必要な缶前ホッパに

投入される様制禦される。

\section{$5 \cdot 2$ ボイラ燃焼機構}

ボイラ燃焼機構として「傾斜波動火格子」を採用している。

これら一連の燃焼機構, 低品位炭の燃焼試験ならびにその特徵 については, 昭和58年度第33回全国選炭大会において発表済みな ので割愛させて頂く。

\section{$5 \cdot 3$ 大気污染防止の結果}

低品位然料の混合燃焼のため, 特に媒じん装置には留意した。 集塵装置としてはこの種ボイラとしては初めてフレクト・オプテ イパルス・バグフィルタを採用した。本装置には炉布保護のため, バグの入口排ガス温度を常に適当な範囲 $\left(120^{\circ} \mathrm{C} \sim 180^{\circ} \mathrm{C}\right)$ に維持す るための熱交換方式による自動排ガス冷却装置を具えた。 [計測結果]

ダスト濃度 $\left(\mathrm{g} / \mathrm{m}^{3} \mathrm{~N}\right)$ 排出基準 0.30 測定値, 0.04 換算値 0.08 全硫黄酸化物量 $\left(\mathrm{m}^{3} \mathrm{~N} / \mathrm{hr}\right) \quad " 17.0$ " 1.4 窒素酸化物量 $(\mathrm{p} \cdot \mathrm{p} \cdot \mathrm{m}) \quad$ " 400 " 180 $5 \cdot 4$ インフラホンの採用

従来, 水管伝熱面の外側に付着する煤や灰を払いおとし，熱伝 達効率を持続させる方法として, 蒸汽噴射式煤吹装置が一般的に 使用されている。今般集塵装置をバグフィルタに絞つた関係上， 従来様式のスートブローは排ガス中の水分含有率を高めるため， 新しい試みとしてインフラソニックブロアー装置を採用した。こ の装置の原理は，圧縮空気により低周波を発生させ，共鳴管を通 して炬内水管群及熱交換器へ一定の音圧振動を作用させて，伝熱 面をクリーニングする方式である。

次に設備概要をご紹介する。

$$
\text { 設 備 概 要 }
$$

（1）ボイラ設備

ボイラ負荷に適応した発熱量の燃料を供給することが出来る。

(3)ケーキ状で搬入される脱水ヶーキの使用には解碎工程をシス テムの一環として取り入れることは，欠くことのできない条件で あり, 同時に特徵でもある。それだけに粘着性の大きい本品の解 砕には, 特殊な解砕機を選定している。また, 解碎時に廃材チッ プの混入も一つの目的であり，微粉との混合は傾斜搬送ベルトコ ンベヤ上で啇量実施されている。

(4)監視室よりのクレーン操作を除き，これ以降の燃料系統は缶 前ホッパの重量計（ロードセル）によつて完全自動運転が可能で ある。これらの装置は $4 \mathrm{t} / \mathrm{hr}$ ボイラおよび $8 \mathrm{t} / \mathrm{hr}$ ボイラの共有 の設備となつているため, (ロードセル) からの信号により缶前上

\begin{tabular}{|c|c|c|c|c|}
\hline \multicolumn{3}{|c|}{ (改) CD-150( $4 \mathrm{t} / \mathrm{h})$} & \multicolumn{2}{|c|}{ (改) $\mathrm{HN}-300(8 \mathrm{t} / \mathrm{h})$} \\
\hline 波動火格子装置 & $5.8 \mathrm{~m}^{2}$ (有効) & 1 台 & $10 \mathrm{~m}^{2}$ (有効) & 1 台 \\
\hline エコノマイザ & $26 \mathrm{~m}^{2}$ & 1 台 & $52 \mathrm{~m}^{2}$ & 1 台 \\
\hline 気予熱器（高温側） & $60 \mathrm{~m}^{2}$ & 1 台 & $132 \mathrm{~m}^{2}$ & 1 台 \\
\hline " （低温側） & $58 \mathrm{~m}^{2}$ & 1 台 & $126 \mathrm{~m}^{2}$ & 1 台 \\
\hline
\end{tabular}

押达送風機 $180 \mathrm{~m}^{3} / \mathrm{min} \times 120 \mathrm{mmAg} 1$ 台 $360 \mathrm{~m}^{3} / \mathrm{min} \times 120 \mathrm{mmAg} 1$ 台 誘引排風機 $380 \mathrm{~m}^{3} / \mathrm{min} \times 250 \mathrm{mmAg} 1$ 台 $760 \mathrm{~m}^{3} / \mathrm{min} \times 250 \mathrm{mmAg} 1$ 台 排ガス冷却用送風機 $75 \mathrm{~m}^{3} / \mathrm{min} \times 50 \mathrm{mmAg} 1$ 台 $150 \mathrm{~m}^{3} / \mathrm{min} \times 80 \mathrm{mmAg} 1$ 台 インフラホン装置 1台 バグフィルタ装置 $\quad 16,600 \mathrm{~m}^{3} / \mathrm{h} \quad 1$ 基 $\quad 33,200 \mathrm{~m}^{3} / \mathrm{h} \quad 1$ 基 


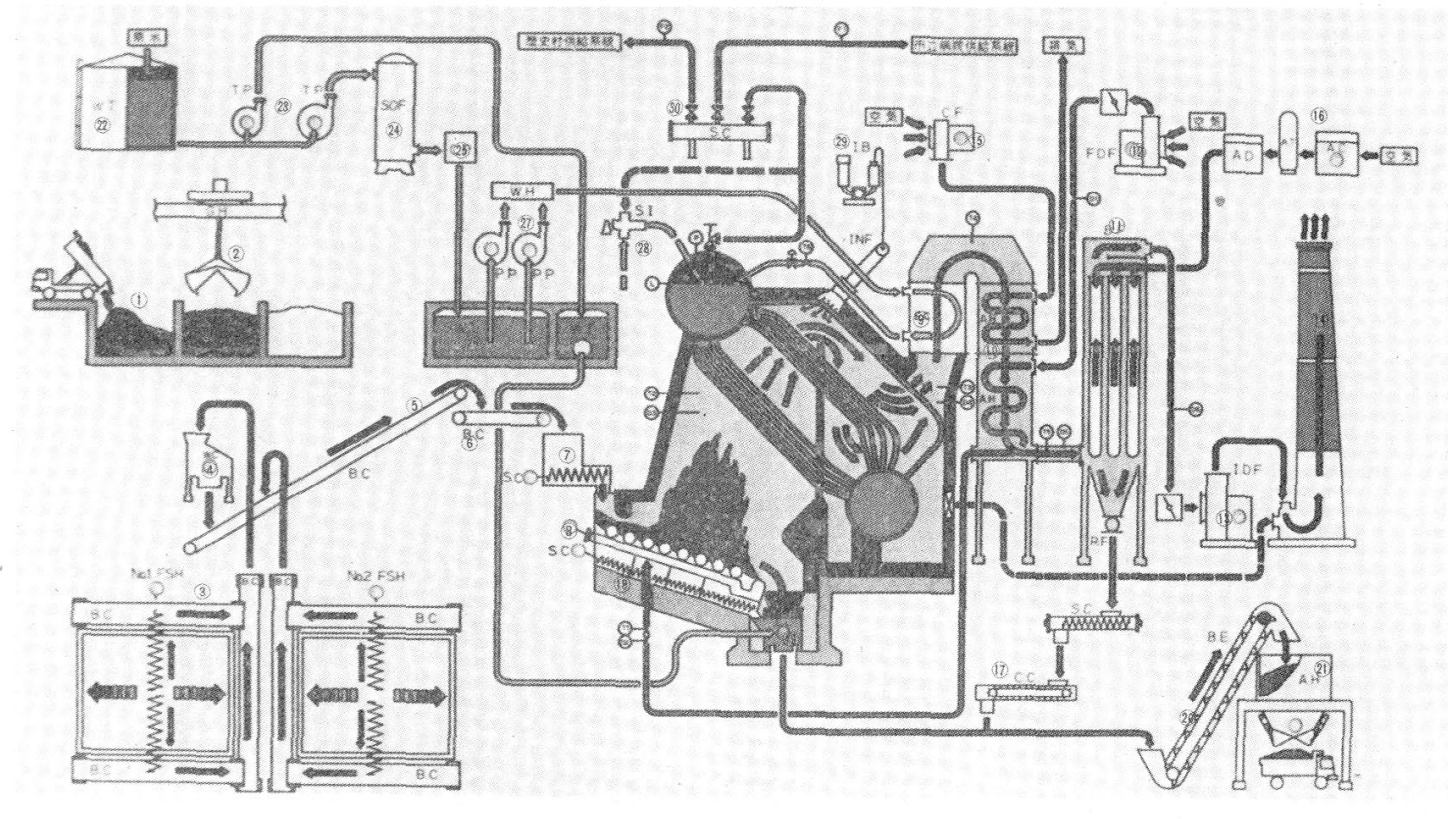

\begin{tabular}{|c|c|c|c|c|c|}
\hline (1) 矮料ピット & (6) 移動式ベルトコンベア & (11)パグフィルタ. & (16) 空気発生機器 & (21) 貯灰ホッバ & (26) 地下軟水槽 \\
\hline (2) グラブクレーン & (7) 缶前供給ホッパ & (12) 押込送風機 & (17) ばいじん搬送装置 & (22) 屋外貯水槽 & (27) ボイラ給水ボンプ \\
\hline (3) 然料サービスホッバ & (8) 波動型ストーカ & (13) 誘引排風機 & (18) 炉下灰出スクリュ & (23) 原水移送ボンプ & (28) スチームインゼクタ \\
\hline (4) 混含解砕機 & (9) エコノマイザ & (14) 煙 突 & (19) 灰出チェーンコンベア & (24) 軟 化器 & (29) インクラホン装置 \\
\hline (5) 傾斜ベルトコンベア & (10) 空気予熱器 & (15) 冷却用送風機 & (20) 揚灰バケットエレベータ & (25) 薬液注入装置 & (30) スチームヘッダ \\
\hline
\end{tabular}

空気圧縮機 空文乾燥機 空気槽

（2）燃料供給設備 貯燃料ビット

グラブバケット天井クレーン サービスホッパ装置

混合解砕機

搬送傾斜ベルトコンベヤ

移動式可巡ベルトコンベヤ

缶前供給ホッパ装置

(3) 灰処理設備

炉下灰出スクリューコンベヤ

灰出チェーンコンベヤ

バケットエレベータ

貯灰ホッパー装置

ばいじん搬送スクリューコンベヤ

ばいじん搬送チェーンコンベヤ

(4) 給水設備 屋外貯水槽 軟 化 水 槽 水封用原水槽 主原水移送ポンプ 補原水移送ポンプ 軟 化 器

第 2 図夕張市熱供給施設概念図

\begin{abstract}
1. $58 \mathrm{~m}^{3} / \mathrm{m}$ in
$1.85 \mathrm{~m}^{3} / \mathrm{m}$ in

$0.29 \mathrm{~m}^{3}$
\end{abstract}

容量 約 $90 \mathrm{~m}^{3}$

$2.8 \mathrm{t}$ 荷重

容量約 $19 \mathrm{~m}^{3}$

$\max \cdot 10 \mathrm{~m}^{3} / \mathrm{h}$

$\max .10 \mathrm{t} / \mathrm{h}$

$\max \cdot 20 \mathrm{t} / \mathrm{h}$

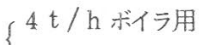

$8 \mathrm{t} / \mathrm{h}$ ボイラ用

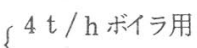

$8 \mathrm{t} / \mathrm{h}$ ボイラ用

$\max \cdot 10 \mathrm{~m}^{3} / \mathrm{h}$

$\max \cdot 10 \mathrm{~m}^{3} / \mathrm{h}$

容量 約 $47 \mathrm{~m}^{3}$

(1)

容量 $150 \mathrm{~m}^{3}$

地下二槽式

地下一槽式

$320 \mathrm{l} / \mathrm{m}$ in $\times 36.5 \mathrm{~m}$

$220 \mathrm{l} / \mathrm{min} \times 22.5 \mathrm{~m}$

$\max \cdot 15 \mathrm{~m}^{3} / \mathrm{h}$

$\begin{array}{ll}1 \text { 台 } & \text { 薬液注入装置 } \\ 1 \text { 台 } & \text { ボイラ給水ポンフ } \\ 1 \text { 基 } & \text { 缶水連続自動ブロー装置 }\end{array}$

3 槽

1 基

2 基

1 台

1 台

1 台

1 基

1 基

1 台

2 台

1 台

1 台

1 基

1 台

1 台

1 台

1 台

1 台

1 台

1 台

1 台

蒸気ヘッダ

(5) 電気 ·計装設備

屋外キュービクル

動力主制御盤

給水ポンプ補助制御盤

スト一補助制御盤

クレーン操作盤 (監視室内)

その他機側操作盤

中央監視室 (監視室内)

(6) 油着火設備

着火用オイルバーナ

オイルサービスタンク

オイル移送ポンプ

地下埋設オイルタンク

5 -5 省エネ化

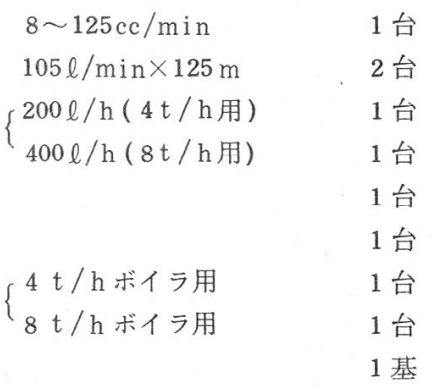

3 面 1 体型

1 基

$\left\{\begin{array}{l}4 t / h \text { ボイラ用 } \\ 8 t / h ホ ゙ イ ラ \text { 用 }\end{array}\right.$

事業の計画掞よび推進に際してランニングコストの問題は重要 な要素である。もちろん燃料費の占める割合が大半であることは 
当然であるが，人件費および動力費等の削堿による影響も見過す わけにはいかない。そのため, 多くの機器装置を備える本施設は, 燃料の代替のみならず，自動化及び省エネ化をできるだけ取り入 れる配虑がなされている。

(1)電力消費の削減を考光, 一部の装置に, 周波数变換による自 動負荷追従運転をさせ，必要最小限の動力供給に止めている。例 えば 2 台の同容量を有するボイラ給水ポンプの場合，ボイラ 2 缶 の共用となつているため, ボイラ負荷に適合するよう，回転制御 と稼働台数を自動的に選定する制御システムを組んでいる。

(2)ボイラより発生する熱ェネルギーのうち, 蒸汽として有効に 利用される以外の損失熱をより多く還元または再利用することは 大きな省エネにつながる。本施設にも次の様な配慮がなされてい る。

(a) エコノマイザ，プレヒータを装備している。

(b) プレヒータは2 段式で排ガスで室内空気を加熱し，一部は然 焼用空気に還元，一部はボイラ室内暖房，その他に利用している。

(c) 自動缶水ブロー装置の冷却水としてボイラ給水を利用し, 熱回収を実施している。

(d) 過剩空気の抑制のためストーカーエンドは水封式とし，水 封位置は電検棒により検出，水封用ポンプの自動運転としている。

(e) バグフィルタスチームトレース用のドレン等を屋外貯水槽 に導き冬期間の貯水凍結防止に役立てる。

b) 昭和 59 年 2 月「低品位炭利用可能性調査研究」( 58 年度中間報告) : 北海道商工観光部資源エネルギー課北海道立工業試験場編 (引用) (f) 各施設への供給蒸汽配管中に必要な多くのドレーントラッ プにはすべて省ェネタイプのものを採用している。

\section{6. あとがき}

代替エネルギー開発が宣伝されている現在，過疎化の進む産炭 都市の活性化を目途に, 先に(株) 石炭の歷史村観光を創立, 今般 その事業の一端として産炭地特有の新燃料を開発利用し, 熱供給 システムを確立した夕張市は，まさに「死中に活」を見出した先 駆的役割を果たしたものとして道関係筋の報告書 ${ }^{\mathrm{b})}$ の中で……「 以上のように，新技術を駆使した設備の安定した運転技術の確立 と低コスト燃料による安価な蒸汽供給によつて, 企業としての成 果が期待される。またこのことは今後同様な事業を検討している 地方自治体にとつても大いに関心があるう。さらに, これらの新 技術による燃料技術の確立は，石油代替を計画している企業群に とつても役立つものと考光る……」と評価されている。今後「モ デル事業」としてのご期待に沿うよう鋭意努力を傾注する所存で ある。

さいごに数年に亘る基礎調査試験中㦝切なご指導を頂いた北海 道立工業試験場, (財) 石炭技術研究所, (社) 日本ボイラ協会, 北 海道大学工学部, 等技術関係の各研究機関検查担当の諸先生方並 びにこの事業に積極的に参加ご協力頂いたメーカーおよび工事担 当各社のご協力に対し深甚なる敬意を表すると共に厚く感謝申し 上げる次第である。

〔新技術紹介〕

\section{（4）スクリューデカンタ型遠心分離機の機能と適用}

\section{1.は じめに}

スクリニーデカンタ型遠心分離機（以下デカンタと略称）は, スクリニーコンベヤを内蔵する回転容器（ボウル）内で, 懸濁液 を連続的に固液分離・分級ないしは脱水する装置であつて, 次の ような一般的特長から選炭プロセスの省力化, 合理化に貢献して きた。

（1）運転操作が全自動連続で且つ容易である。

（2）供給液の濃度変動による性能上の影響が少ない。

(3) 高い脱水度が得られる。

(4) 大容量でしかも設備スペースの小さい装置が可能である。 デカンタの分離機構その他の概要は前々回の新技術紹介 ${ }^{1)}$ で説 $^{-1}$ 明しているので, 本稿ではその機能についてやや詳細に考察して みたい。上記資料 ${ }^{1)}$ のデカンタ構造図を第 1 図に引用する。

\section{2. 操 作 機 能}

デカンタのボウル内では次の 3 機能により投入物の処理操作が 進行している。すなわち分級機能と固形物搬送機能と濃縮・脱水 機能とである。以下それぞれの機能について考察を進める。

\section{$2 \cdot 1$ 分級機能}

デカンタに投入された懸濁液はその沈降分離域（主としてボウ ル円筒部) において, 粒径の大きい粒子は沈降した後スクリュー

1）戸田敏行 : 日本釷業会誌, 98 [1136], 1068～1070（1982）
コンベヤで運び去られ，沈降しきれなかつた微細粒子は分離液と 共に堰をこえてボウル外に排出される。この分離機構はちようど 液体サイクロン分級器のそれと類似している。

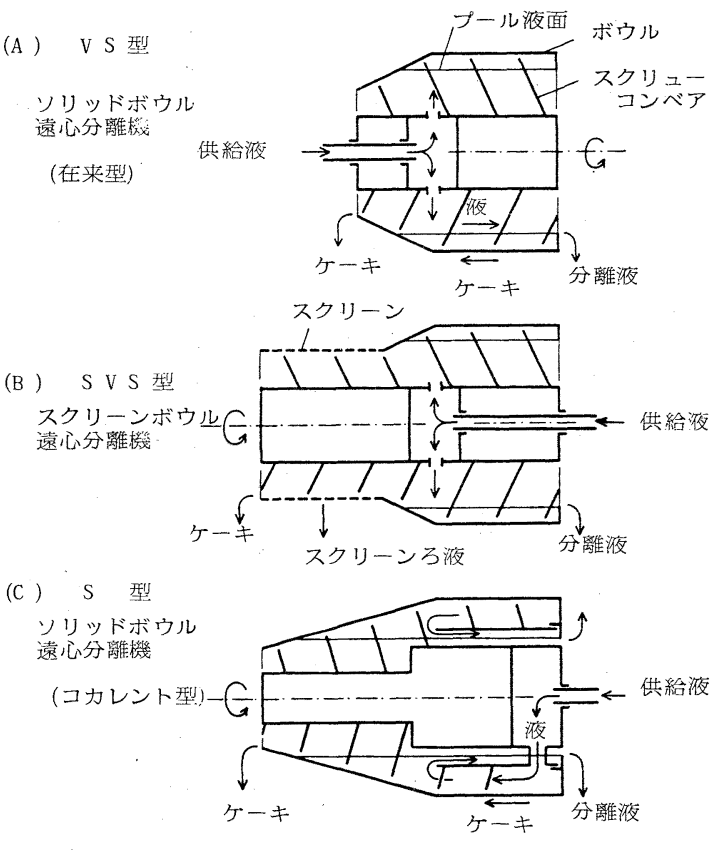

第1図 スクリニーデカンタ型遠心分離機の分離機構 